\title{
«Aquí yace Sebastián de Ocampo, que Dios perdona» (Perfil biográfico de un mercader indiano $† 1514) /$
}

\author{
«Here lies Sebastián de Ocampo, whom God forgives» \\ (biographical profile of an «Indiano» merchant $\uparrow 1514$ )
}

Carmen Mena García

Universidad de Sevilla

El gallego Sebastián de Ocampo ha pasado a la historia como marino y explorador, sobre todo a raíz de su expedición para averiguar la insularidad de la isla de Cuba en 1506. Se le reconoce también por su relación con Vasco Núñez de Balboa, quien lo nombró por apoderado en defensa de sus intereses ante la Corte. El análisis de su testamento nos revela otras facetas, desconocidas hasta la fecha, de este curioso personaje de la época de la conquista de América: además de su círculo familiar más inmediato, sus vínculos con la isla de la Gomera, donde estuvo avecindado por algún tiempo, y su actuación en Santo Domingo, en donde transcurrieron sus últimos años, y en Sevilla, donde falleció, como cambista y mercader del comercio atlántico con socios y protectores convenientemente instalados en las altas esferas del poder.

Palabras Clave: Sebastián de Ocampo; Descubrimiento y conquista; Mercader; Comercio atlántico; Testamento.

Galician Sebastian de Ocampo has gone down in history as sailor and explorer, particularly after his expedition to ascertain Cuba's insularity in 1506. He is also well known for his relationship with Vasco Nuñez de Balboa, who appointed him as representative to defend his interests before the Court. The analysis of his will reveals other facets of this interesting figure of the America's conquest period, which were unknown so far, such as: more than his closest relatives; his connections with the Gomera Island, where he lived for a period of time; his actions in Santo Domingo, where he spent the last years of his life; and in Seville where he died being a money changer and merchant for the Atlantic trade with partners and protectors from the highest political circles.

KEYwords: Sebastián de Ocampo; Discovery and conquest; Merchant; Atlantic trade; Will. 


\section{Introducción}

Hace ya bastantes años Manuel Giménez Fernández daba noticias sobre el paradero del testamento de un interesante y desconocido personaje de la exploración y conquista del Nuevo Mundo: el gallego Sebastián de Ocampo. Según el erudito historiador, descansaba en los fondos del Archivo de Protocolos Notariales de Sevilla, concretamente entre los polvorientos documentos que había expedido allá por 1514 un laborioso escribano público llamado Manuel Segura. ${ }^{1}$ Quien sea aficionado a esta temprana época sabe bien que la desaparición de muchos testimonios de aquellos apasionantes años agiganta el valor de cualquier hallazgo y acrecienta su interés. También se explica por ello la pasión que estimula a los detectives de la historia, siempre a la caza de una pista valiosa, de un dato escurridizo, o de cualquier respetable evidencia a sabiendas de que no existe una historia definitiva. Pero, por increíble que parezca hasta la fecha, nadie, que sepamos, se ha preocupado de localizar el testamento de este curioso personaje y desentrañar su apasionante contenido.

En efecto, son muchos los claroscuros que envuelven su figura. Ángel de Altolaguirre ya advirtió que Sebastián de Ocampo, pese a haber desempeñado un importante papel en las relaciones de Vasco Núñez de Balboa con la Corte, «ha pasado desapercibido a los historiadores», y tiene razón. ${ }^{2}$ Si se repasa con atención su perfil histórico, puede concluirse que nuestro hombre es hoy conocido más por sus vínculos con otros famosos personajes de la historia del Nuevo Mundo que por sí mismo. Se le recuerda por haber acompañado al gran Almirante Cristóbal Colón en su segundo viaje (1493). También por sus relaciones con el descubridor del Pacífico, el extremeño Vasco Núñez de Balboa, con quien seguramente entabló una sincera amistad durante su estancia en Santo Domingo y luego en el

1 En referencia al citado testamento anota Giménez Fernández, 1969, en I, 284, lo siguiente: «Este documento... se halla en APS, oficio IV de Manuel Segura, lib. II, fol. 681 vto. y ha sido publicado en el Catálogo de los fondos americanos, tomo IV, núm. 391». Sin embargo, una rápida ojeada a la obra indicada nos demuestra que lo único que se transcribe en ella es un breve extracto de tan sólo unas líneas, pero en modo alguno el interesantísimo documento en su totalidad. El testamento de Ocampo se reproduce parcialmente en el riquísimo inventario de los fondos de protocolos notariales que nos legó Enrique Otte («Fondo Otte») y que he podido consultar gracias a las facilidades prestadas por el profesor Jaime Lacueva, al cual quiero dar las gracias en estas páginas. No obstante, y para asegurarme de la veracidad de la información contenida, también he revisado el documento original (Archivo Histórico de Protocolos de Sevilla, en adelante AHPS, 2209) y contrastado rigurosamente su contenido, corrigiendo o añadiendo allí donde lo estimé necesario.

2 Altolaguirre, 1914, LXV. 
Darién. Es cierto: a Ocampo se le atribuye el honor de haber sido el primer europeo que en 1506 circunnavegó Cuba demostrando su insularidad, pero el mérito le fue arrebatado hace unos años por el historiador Juan Manzano, quien niega que él fuera el primero. ${ }^{3}$

En las páginas siguientes trataremos de desvelar aspectos sumamente reveladores y desconocidos hasta la fecha sobre la figura de Sebastián de Ocampo, que él mismo se encargó de transmitirnos en su testamento, redactado en Sevilla en el verano de 1514, poco antes de su fallecimiento. La rigidez de los escritos oficiales, el apego a los relatos excesivamente épicos y muchas veces contradictorios de los cronistas de Indias nunca podrán competir con el valor testimonial de una de las fuentes históricas más expresivas del hombre del Antiguo Régimen, como es el material testamentario. Ya lo decíamos en otra ocasión: «La muerte, como reflejo, como síntesis de valores y de conductas, constituye una materia historiable de primer orden, tanto como lo es la vida». ${ }^{4}$

\section{Sebastián de Ocampo o la fuerza del destino}

Cuando Sebastián de Ocampo vino a este mundo en la humilde aldea de Tuy (Galicia), allá por la segunda mitad del siglo XV, nadie, ni siquiera su padre Pedro Hernández, habría podido imaginar las fabulosas aventuras que aguardaban a aquel niño. La caprichosa rueda del destino iniciaba su andadura, pero también es cierto que los denodados esfuerzos de aquella pequeña criatura por hacerse un hueco en la vida, desde el mismo momento en que se convirtió en un mozalbete despierto y ambicioso, hicieron todo lo demás. Sí, cualquiera podría pensar que el destino lo empujaba hacia nuevos horizontes, muy lejos del minúsculo terruño gallego que lo vio nacer. Lo atraía con fuerza hacia ese «Mar Tenebroso» poblado de fantasmas y seres mitológicos en donde nadie osaba adentrarse y cuya antesala - las islas Canarias - estaban siendo anexionadas a la corona de Castilla por las huestes de grandes señores feudales. Transcurridos algunos años, dos espacios atlánticos: Las Canarias y el Nuevo Mundo se convirtieron en el escenario natural de las aventuras de este joven gallego. Si alguien le hubiera preguntado, él mismo confesaría que allí transcurrieron sus años

3 Manzano, 1988, II, 226 y ss.

4 Mena, 2004, 5. 
más felices. Por entonces, pensó sin duda, que agotaría sus últimos días cómodamente instalado en alguno de aquellos privilegiados enclaves de la balconada atlántica. Pero una vez más el caprichoso destino impuso sus dictados: un tórrido mes de julio de 1514 la muerte le sorprendió muy lejos: en Sevilla, el gran centro de negocios del Nuevo Mundo, a donde, siendo ya un hombre maduro había acudido una vez más para despachar algunos asuntos de importancia.

¿Qué sabemos de su etapa española, tan desconocida hasta estos momentos? Lo primero que llama la atención, tras una lectura detenida de su testamento, es la vinculación de nuestro personaje con las islas Canarias, en concreto con la Gomera, esa isla sujeta al señorío de los Peraza, de la que se dice que nunca fue conquistada. Como tantos otros españoles que se sintieron atraídos por la aventura atlántica, Sebastián de Ocampo también participó en la conquista de las Canarias y luego se avecindó en la isla de la Gomera durante algunos años, antes de pasar a las Indias, y allí le acompañó la fortuna, pues amasó un importante patrimonio en fincas y haciendas de labor, instaladas todas ellas en un frondoso paraje conocido como «el Valle del Gran Rey». Seguramente otros miembros de su familia le siguieron hasta las Canarias, desde luego lo hizo su primo Alonso de Ocampo, quien llegó a ser gobernador de la Gomera por varios años.

Hombre combativo y de espíritu inquieto, Sebastián de Ocampo permaneció en la isla el tiempo suficiente como para hacerse rico y disfrutar de amoríos fugaces que le reportaron varios hijos. El primero de éstos surgió en el mismo ámbito familiar aunque desconocemos en qué grado de consaguinidad. La dama en cuestión se llamaba María de Ocampo y era, como el mismo Sebastián, vecina de la Gomera. Con ella tuvo a Gonzalo de Ocampo, su hijo natural, puesto que nunca legitimó esta unión. Hubo otra mujer que debió significar mucho menos en la vida de nuestro personaje puesto que llegada la hora de su muerte no supo o no quiso recordar su nombre. Sin embargo, tuvo un hijo de esta misteriosa dama con el que mantuvo relaciones más estrechas que con el anterior, pues incluso le acompañó a las Indias. Se llamó Simón de Ocampo y por lo que sabemos en 1514 - año del fallecimiento de su padre - estaba avecindado en la isla de San Juan. El último miembro de la prole de Sebastián fue la joven María de Ocampo, todavía en edad casadera a la muerte de su padre, fruto reconocido de los amoríos con una vecina de Tenerife, de nombre Margarida Marrana. 
Alguien aseguró años más tarde que Sebastián de Ocampo era hidalgo y criado de la reina Isabel; dijo también que llegó a las Indias por primera vez en 1493, acompañando a Colón en su segundo viaje, y deberíamos confiar en este testimonio pues procede nada menos que del mismísimo Bartolomé de Las Casas. ${ }^{5}$ El apasionado fraile dominico y cronista de excepción de aquellos desmesurados años ha sido objeto de numerosas críticas por su fanatismo y resentimientos personales, pero al margen de sus errores, más que comprensibles por la abundancia de datos y de personajes de los que hizo acopio en su extensa obra, estaba bien informado porque vivió una buena parte de su vida en las Indias y tuvo ocasión de conocer directamente a muchos actores de aquella apasionante historia. ¿Qué grado de amistad mantuvo con Sebastián de Ocampo? Eso nunca lo sabremos, aunque es indudable que lo conocía bien ya que ambos - Las Casas y Ocampo - aunque no viajaron, como se ha dicho, en la misma flota, coincidieron en La Española y probablemente en Cuba el tiempo suficiente como para compartir largas y distendidas charlas. ${ }^{6}$

Por entonces Sebastián de Ocampo se había instalado definitivamente en Santo Domingo, era respetado por sus vecinos, quienes lo consideraban «harto hombre de bien», y gozaba de una inmejorable situación económica. Ya había vivido lo suficiente como para saber que en aquella complicada red de intereses y turbios manejos del comercio atlántico era necesario disponer de socios y amigos convenientemente instalados a uno y otro lado del océano, de cómplices silenciosos y protectores influyentes, si se pretendía medrar con rapidez. En efecto, era un hombre acaudalado y para asegurar el éxito de sus operaciones aprendió a moverse como pez en el agua en las altas esferas del poder, ya fuera en la Corte o en la mismísima Casa de la Contratación de Sevilla, organismo rector del comercio indiano. Y vaya si lo consiguió. Por lo pronto se asoció en diferentes negocios con el ambicioso tesorero real de La Española Miguel de Pasamonte,

5 Las Casas, 1957, II, 100. «Para este descubrimiento (de la isla de Cuba) envió por capitán a un hidalgo gallego, llamado Sebastián de Campo, criado de la reina doña Isabel, de los que habían venido con el primer Almirante cuando vino a poblar esta isla el segundo viaje».

6 Las Casas, 1957, I, 437. El propio Las Casas dice haberlo conocido durante su estancia en La Española y asegura que era «harto hombre de bien». No obstante, guardamos reservas sobre la condición de hidalgo de Ocampo, de la que todos los historiadores se han hecho eco a partir de Las Casas, pues de haber sido así el gallego hubiera hecho gala de su hidalguía en su testamento. Recordemos que el fraile dominico viajó a las Indias por primera vez en 1502 en compañía de Nicolás de Ovando. Mientras que fue su padre, Pedro de las Casas, quien había llegado a La Española en 1493 en el segundo viaje de Colón. 
incondicional amigo de Lope Conchillos y secretario personal del rey Fernando. Disfrutaba también de la amistad de todas las personas importantes de la isla, comenzando por el propio gobernador Ovando, habiendo participado con muchas de ellas, incluso con Diego de Nicuesa, en numerosas actividades mercantiles. También se había preocupado de estrechar lazos en la Corte con algunos de los personajes más influyentes de aquellos momentos, entre ellos Francisco de los Cobos, antiguo miembro de la corrompida camarilla fernandista y luego todopoderoso secretario personal del joven Carlos I, así como de un destacado funcionario de la Casa de la Contratación, el factor Pedro de Isásaga, por lo demás contino de la Casa real.

¿Nuestro influyente personaje arrastraba un oscuro pasado? La historiografía tradicional ha sostenido por mucho tiempo que un tribunal español lo condenó a muerte en 1501 por un delito de homicidio y luego de avecindarse en Madrid le conmutó la pena en destierro perpetuo a las Indias. Una injusta lacra de la que convendría limpiarlo ya para siempre. Una vez más fue el historiador Giménez Fernández el primero en proporcionar la noticia, dando pie a la confusión. Luego, por inercia, otros investigadores se hicieron eco de la misma, sin caer en la cuenta de que se trataba de dos personajes distintos, aunque con el mismo nombre. En efecto, refiriéndose a los colonos que integraban la expedición de Nicolás de Ovando a las Indias (1502), anotaba el citado autor lo siguiente:

Gonzalo de Ocampo, que probablemente emigró para acompañar a su hermano Sebastián, a quien se había conmutado en destierro la pena de muerte en que incurriera por un homicidio cometido en Jerez de los Caballeros.?

Sabemos que el referido Gonzalo de Ocampo era hijo de un tal García de Ocampo, y natural de Cáceres, al igual que sus otros hermanos que le acompañaron a las Indias en la misma flota, incluido uno llamado Sebastián. De todos los hermanos de esta familia Ocampo, el más conocido parece haber sido Gonzalo, pues además de amigo personal de las Casas, se hizo famoso por su destacada intervención en la aventura lascasiana de Cumaná. ${ }^{8}$ La otra familia Ocampo, a la que sin duda pertenecía

7 Giménez Fernández, 1960, II, 596.

8 Véase la biografía de este Gonzalo de Cumaná en Ibidem, II, 1058. 
nuestro Sebastián, era de origen gallego y que sepamos no guardaba ningún vínculo familiar con los Ocampo extremeños. Por lo que se aprecia, dos hombres llamados Sebastián de Ocampo compartieron aventuras en un mismo escenario. Consideramos que en adelante deberían deslindarse sus trayectorias personales, tanto como sus éxitos o fracasos, por una simple cuestión de fidelidad histórica.

Pero regresemos a nuestro relato. Sebastián de Ocampo no aparentaba tacha legal alguna cuando el poderoso gobernador de la isla, Nicolás de Ovando, en un gesto de confianza, lo comisionó para circunnavegar Cuba con dos barcos y comprobar si era una isla. Las Casas recordaba años después que:

Acordó también por este tiempo, que era el año de quinientos ocho, el comendador mayor, enviar a descubrir del todo a la isla de Cuba, porque hasta entonces no se sabía si era isla o tierra firme, ni hasta dónde su largura llegaba, y también ver si era tierra enjuta, porque se decía que lo más era lleno de anegadizos, ignorando lo que el Almirante, cuando la descubrió el año de noventa y cuatro, había visto en ella. ${ }^{9}$

Por su parte Oviedo se mostraba más impreciso, aunque de sus palabras parece desprenderse que el viaje debió producirse en algún momento del año 1509 y no en 1508, como aseguraba el fraile dominico:

Poco tiempo antes que el comendador mayor de Alcántara, don frey Nicolás de Ovando, fuese removido de la gobernación de aquestas partes, envió con dos carabelas y gente a tentar si por vía de paz se podría poblar de cristianos la isla de Cuba, y para sentir lo que se debía proveer, si caso fuese que los indios se pusiesen en resistencia. Y a esto envió por capitán a un hidalgo llamado Sebastián de Ocampo. ${ }^{10}$

No debe sorprendernos este baile de cifras. Las crónicas de aquellos tempranos años no siempre aciertan en sus informes; algunas se caracterizan por sus apasionados relatos y la mayoría están plagadas de errores que se han transmitido por generaciones. Nada de esto ayuda a la labor pesquisidora del juicioso historiador. Por fortuna el hallazgo de cualquier dato, por insignificante que este sea, puede arrojar luz allá donde hubo tinieblas.

9 Las Casas citado por Mira Caballos, 1996, 199-205.

10 Fernández de Oviedo, 1959, II, 112.

11 Mira Caballos, 1996, 56-206, 199-205. 
Tal parece haber sucedido en este caso. Un sencillo apunte contable ha llevado al historiador Esteban Mira a la certeza no sólo de que la expedición de Ocampo debió de producirse en el verano de 1506, sino de que ésta tuvo escasa trascendencia, pues como ya observara Oviedo: «(Sebastián de Ocampo) fue a aquella isla e tomó tierra en ella, pero hizo poco». ${ }^{11}$ Así lo confirmaba la correspondencia de años posteriores de la cual se deduce que todavía la isla de Cuba no había sido explorada por completo. Aún más, se duda incluso de que el mérito pueda achacarse al hidalgo gallego, cuyas dotes como marino y explorador parecen apagarse, en vista de este fracaso, como un candil sin aceite. Ya lo señaló el gran colombinista Juan Manzano en una magistral obra dedicada a los Pinzones: no fue Sebastián de Ocampo, como siempre se ha admitido, sino Vicente Yáñez Pinzón y Juan Díaz de Solís quienes en 1508 circunnavegaron por primera vez la isla de Cuba. ${ }^{12}$ Aquella expedición a la isla de Cuba que Oviedo desmerece con la lapidaria frase de «hizo poco» le ha valido a Sebastián de Ocampo, ya para la posteridad, el reconocimiento de «gran marino y explorador». Una injusticia histórica, sin duda.

Otro suceso, bien conocido, lo puso en contacto con Vasco Núñez de Balboa, el famoso descubridor del Pacífico, quien desde 1511 gobernaba la colonia de Santa María de la Antigua, en las tierras selváticas del Darién, por nombramiento del virrey Diego Colón. Siempre quedará la duda de si Sebastián de Ocampo era ya amigo de Balboa en aquellos tiempos en que ambos residieron en la isla o simplemente venía predispuesto a su favor, ya fuera por intereses comunes o por una simple cuestión de empatía, cuando lo visitó por última vez en el asiento del Darién. Pero lo que nadie podrá negar es que su llegada resultó providencial para Balboa. ${ }^{13}$

A fines de 1512, respondiendo a la llamada desesperada de los hombres del asiento de Santa María, el virrey Colón enviaba desde Santo Domingo a los hambrientos colonos del Darién dos embarcaciones cargadas de alimentos y otros suministros que fueron recibidos con enorme júbilo. Por entonces Balboa aseguraba que los hombres estaban «tan al cabo que si mucho tardara el remedio, cuando viniera no fuera menester porque no hallara qué remediar según el hambre nos ha tratado». Los barcos viajaban a cuenta de su armador, que no era otro que Sebastián de Ocampo, quien seguía avecindado en La Española, y aunque estaba previsto que el

12 Manzano, 1988, II, 344.

13 De este encuentro tratamos en nuestro último trabajo. Véase Mena, 2011, 175, 176. 
viaje durase veinte días finalmente se demoró hasta cerca de dos meses, después de hacer escala en la isla de Cuba. ${ }^{14}$

Ningún cronista del Darién nos ha explicado los verdaderos motivos por los que el gallego Ocampo decidió convertirse en amigo y confidente de Vasco Núñez durante su estancia en el Darién. Y más aún teniendo en cuenta el crispado ambiente que se había instalado en la colonia. Ciertamente a la llegada de Ocampo el modesto enclave español de Santa María de la Antigua no era precisamente un remanso de paz. En ausencia del gobernador Alonso de Ojeda, que, enfermo, había viajado a Santo Domingo para nunca más regresar, dos bandos andaban enfrentados: el legitimista integrado por los partidarios del bachiller Martín Fernández de Enciso, lugarteniente de Ojeda, y el facineroso en el que militaban los amigos y adeptos de Vasco Núñez, que pugnaba abiertamente por hacerse con la jefatura. Tras un golpe de mano magistral, Balboa logró finalmente que Enciso fuera capturado y enviado preso a España junto con su proceso de destitución, al mismo tiempo que se le confiscaban todos sus bienes. En aquellos precisos momentos el ambicioso extremeño había triunfado sobre sus enemigos, y había conseguido erigirse como el caudillo indiscutible de la colonia, pero todavía quedaba un largo camino por recorrer. Ante todo Balboa, el protegido del virrey Colón, era consciente de la precariedad de su jefatura y de la necesidad de que el monarca aprobase su actuación con un cargo en propiedad. ${ }^{15}$ ¿Cómo se interpretarían allá en la distante Corte

14 Archivo General de Indias (en adelante AGI), Indiferente General, 419, 5, 110r-110v/ 344r344v. El Rey: «Por parte de los herederos de Sebastián de Ocampo, ya difunto, me es hecha relación que los nuestros jueces e oficiales que residen en esa dicha isla le enviaron a Castilla del Oro por capitán de dos naos en que iban bastimentos para la gente que a la sazón residía en la dicha Castilla del Oro e que al tiempo que le despacharon para hacer el dicho viaje asentaron y concertaron con él que hubiese de estar allá veinte días y no más, y que a causa de no ir bien cargadas las dichas naos, como convenía, e el tiempo recio que hizo se detuvieron las dichas naos cincuenta días, por lo cual los dichos jueces e oficiales le pusieron demanda de ochocientos castellanos de oro e para estar a derecho e pagar lo juzgado diz que dio fianzas en la dicha cuantía de que ha recibido agravio e daño porque el dicho Sebastián de Ocampo diz que fue el dicho viaje más por nos servir que por su interés, e que más de esto las dichas naos ganaron su flete en el dicho tiempo e que en determinar en el negocio por los dichos jueces a quien toca recibirían mucho daño». Real Cédula al licenciado Ibarra, juez de residencia de la Isla Española y repartidor de los indios de ella, para que se informe y provea en justicia en el asunto que piden los herederos del difunto Sebastián de Ocampo. Valbuena, 22 de octubre de 1514.

15 En 1511 el virrey Diego Colón había designado a Balboa gobernador en la Tierra Firme y dio cuenta de su decisión al monarca el 10 de septiembre del mismo año. El cargo fue luego confirmado por el monarca aunque en interinidad. Una Real Cédula fechada en Zaragoza el 23 de diciembre de 1511 nombraba a Vasco Núñez «gobernador y capitán de la provincia del Darién... entretanto que mandamos proveer de gobernador e justicia de la provincia del Darién en la Tierra Firme». Altolaguirre, 1914, LXXXII y apéndice 2. 
castellana los métodos nada ortodoxos de los que se había valido para apartar del mando al alcalde mayor Enciso? ¿Y cómo se defendería éste en los círculos cortesanos en donde gozaba de amigos tan influyentes? Balboa no erraba en sus temores. ${ }^{16}$ Necesitaba ganarse el favor real y decidió recurrir a Sebastián de Ocampo quien providencialmente se disponía a viajar a España para atender sus asuntos. Balboa lo nombró su apoderado en la corte con la misión de ensalzar sus méritos y contrarrestar los ataques de sus enemigos, al tiempo que le confiaba trescientos setenta pesos de oro de minas para el rey, complemento de una partida anterior de otros quinientos pesos entregada a los procuradores del Darién, Caicedo y Colmenares, cuando éstos zarparon para la metrópoli unos meses atrás, así como diversos productos indígenas y un esclavo indio, que seguramente ya hablaba algunas palabras en castellano, para que explicase los métodos utilizados por los nativos en los lavaderos auríferos de la Tierra Firme. Sebastián de Ocampo recibió también varios escritos, entre ellos una larguísima carta redactada por el propio Vasco Núñez el 20 de enero de 1513 y que constituye uno de los escasos testimonios personales que ha llegado hasta nuestros días. ${ }^{17}$ En ella Balboa comunicaba al monarca los últimos sucesos acaecidos en la colonia, ensalzaba sus propios méritos y denunciaba los de sus enemigos, en especial los de Ojeda y Nicuesa, efímeros gobernadores de Urabá y Veragua. Pero Sebastián de Ocampo debía cumplir con otra misión: la de entrevistarse personalmente con el monarca, dándole a conocer «la verdad» de los últimos sucesos de la colonia, siempre, por supuesto, en beneficio del extremeño. «Para que mejor sea vuestra Alteza informado de todo lo que acá pasa — escribe Balboa- envío a Sebastián de Campo, suplico a vuestra Alteza le dé entero crédito porque de mí va informado de toda la verdad y de todo lo que en esto se puede hacer en servicio de vuestra Alteza y lo que es menester para la tierra». Una vez ultimados

16 Enciso no sólo consiguió ser absuelto de todos sus cargos sino que fue nombrado alguacil mayor de la Tierra Firme en recompensa por los daños ocasionados por Balboa. Durante el largo tiempo que permaneció en la corte tuvo tiempo, además, de participar en las sesiones de la Junta de Valladolid de 1513 en las que se debatieron los derechos que España tenía de hacer la guerra a los indios y en donde se gestó el famoso «Requerimiento». El bachiller brillaba con luz propia en los círculos más influyentes y junto a los más prestigiosos teólogos y canonistas de la época en medio de la polémica desatada por la conquista de las Indias y de sus nuevos súbditos. Giménez Fernández, 1960, II, 467, 469, 494, denuncia la intransigente postura de Enciso con respecto a los indios y considera que sus argumentos expuestos en Valladolid no fueron más que «disparates de un arribista». Desde luego en su obra no oculta su antipatía por el bachiller al que tacha de «rabioso colonista» y de «indófobo».

17 Dado su interés, la carta de Balboa ha sido reproducida en numerosas ocasiones, entre otros por José Toribio Medina, 1913, II, 129 y siguientes. 
los asuntos más urgentes, el apoderado Ocampo abandonó el Darién dispuesto a cumplir con su misión, pero - como ya adelantamos- fue detenido en Cuba más tiempo del acordado y no arribó a La Española hasta febrero o marzo de 1513, siendo severamente amonestado por los oficiales de la isla, quienes le impusieron por su tardanza una multa de 800 castellanos de oro. ${ }^{18}$

\section{Cuando la muerte acecha: El legado testamentario de Sebastián de Ocampo y el encargo de Balboa}

En la vida de cualquier ser humano no hay un acto más auténtico que cuando este se despide de la vida y de su círculo afectivo y familiar más cercano. Como ser social, acude a un escribano para redactar su testamento, legalizando así, mediante escritura pública, su última voluntad en lo que a la transmisión de sus bienes o herencia respecta. Atendiendo a sus profundas convicciones religiosas y a los dictados de la Iglesia católica, el hombre del Antiguo Régimen cumple, además, con un requisito inexcusable al preocuparse por la salvación de su alma. Y es que «el testamento era concebido entonces como un ritual de salvación, obligado y casi sacramental, que garantizaba a los fieles mediante un acto público, escrito ad pías causas, la reconciliación eterna y el camino hacia la otra vida a cambio de una serie de legados piadosos. En definitiva, parafraseando a Jacques Le Goff, el testamento no era otra cosa que "un pasaporte hacia el cielo"»», ${ }^{19}$ aunque para un mercader poderoso, como era Sebastián de Ocampo, representaba sobre todo la postrera ocasión de dejar sus asuntos materiales bien en orden, antes de abandonar definitivamente la tierra.

18 Véase nota 14. En el viaje de regreso Ocampo fondeó en el puerto de Jagua (actual Cienfuegos); allí quedó varado uno de sus barcos, que ya hacía agua, junto a cuatro hombres que quedaron custodiando varias vasijas de vino. El gobernador Diego Velázquez conociendo su llegada lo hizo llamar a su presencia recibiéndolo con todos los honores. El fraile Las Casas recoge este suceso. Dice así: «Supo Diego Velázquez que había llegado un navío y con él ciertos españoles al puerto de Xagua...por lo cual envió una canoa bien esquifada de indios remadores con una carta que les decía que se viniesen a donde él estaba, quienquiera que fuesen. Llegada la carta, holgóse mucho el capitán, que era Sebastián del Campo, que fue el que envió el comendador mayor a que bojase aquella isla el año de ocho, según que arriba...dijimos; holgáronse también los que con él venían. Éste había cargado un navío, suyo o con otros en compañía, de vino y mantenimientos para vender a los que estaban en el Darién, y despachada su mercadería, tornábase para esta isla... y vínose (al puerto de Xagua) a donde Diego Velázquez estaba... el cual muy graciosamente recibiólo». Las Casas, 1957, II, 240-241 y 249.

19 Le Goff, 1982, 240. Citado por Mena, 2004, 13. 
Cuando por fin llegó a Sevilla en el verano de 1514, Sebastián de Ocampo no tuvo apenas ocasión de despachar los negocios que le traían a la capital hispalense. Muy pronto cayó postrado en cama de una grave enfermedad que lo conduciría a la muerte. Como solía hacer siempre que visitaba Sevilla, se alojó en la casa de su primo, el mercader Alonso de Noya, situada en el barrio de San Marcos; con él y su familia mantenía unas relaciones muy estrechas, casi de hermano. Durante aquellos días Alonso se encontraba ausente, pero su esposa Inés Romes, hija de un próspero curtidor sevillano, y su hija Beatriz atendieron solícitas al enfermo procurándole toda clase de cuidados.

Sintiendo la llamada de la muerte, el 25 de junio Sebastián ordenó llamar al escribano Manuel Segura para dictarle su testamento, pero días más tarde recordó algunos asuntos de importancia que había dejado sin resolver y añadió nuevas cláusulas en sendos codicilos, ${ }^{20}$ fechados en 26 de junio, el primero, y en 3 y 6 de julio los dos restantes. Siempre había sido un amigo fiel y un hombre de palabra, por lo tanto no se olvidó de la promesa contraída con Vasco Núñez en el Darién, pero sabía que la vida se le escapaba sin darle tiempo para cumplir el encargo, y por eso decidió transferir los poderes que tenía del extremeño a su primo Alonso de Noya, junto a un todavía desconocido ${ }^{21}$ Francisco de los Cobos, oficial del secretario real de las Indias Lope de Conchillos. En las citadas escrituras, ${ }^{22}$ fechadas también un lunes, 26 de junio, que se han conservado acompañando al testamento, Sebastián de Ocampo concedía a su primo por los gastos que generaran las negociaciones cuarenta ducados, así como una mula pardilla, «que yo tengo ensillada y enfrenada», con la severa advertencia de que le sería retirado el legado, si no cumplía con el encargo. El formalismo legal era parte consustancial del carácter español, tanto o más que la religiosidad. Por eso, cualquier asunto, por nimio que éste fuera, requería de complicadas formalidades jurídicas, siempre ante la presencia de un escribano público, que era el encargado de atestiguarlo. En este caso

20 «A la declaración de la última voluntad hecha con posterioridad al testamento, con el fin de modificar, añadir o limitar su contenido, se le llamó codicilo y fue menos solemne que aquél». Como norma general no invalidaba al precedente, si no era por voluntad explícita del autor. Contreras, 2000,36 .

21 El documento en cuestión registra el apellido Cobos, pero deja un espacio en blanco en el lugar correspondiente al nombre, lo cual demuestra, según Giménez Fernández, «cuán poco conocido era aún el después famoso ministro de Carlos V», 1960, I, 284.

22 Las escrituras notariales con la transferencia de poderes fueron publicadas hace ya muchos años por Ángel de Altolaguirre y Duvale, 1914, apéndices 20 y 21. 
alguien pensó que sería necesario contar con un escrito de los oficiales de la Casa de la Contratación ratificando el encargo. Y así, un mes más tarde, puesto que Noya no había regresado aún a Sevilla, un vecino de esa ciudad amigo del finado, llamado Juan de Ledesma, ${ }^{23}$ compareció ante los oficiales de la Casa de la Contratación Juan López de Recalde y Pedro de Isásaga solicitando que éstos otorgasen «un mandamiento compulsorio» para que el escribano Manuel Segura le diese traslado del «dicho poder sustituto y la dicha obligación que el dicho Sebastián de Ocampo otorgó al dicho Alonso de Noya».

\section{Mandas piadosas y lugar de enterramiento}

Lo primero que despierta nuestra atención cuando repasamos las escrituras testamentarias del gallego Ocampo es la ausencia de preámbulos y fórmulas piadosas invocando la protección divina, o aludiendo a dogmas religiosos, tan característicos y abundantes en otros testamentos del Antiguo Régimen. En este caso no hay lugar para protocolos religiosos, pues se pasa - diriamos que abruptamente - de la intitulación, que encabeza el documento, a la declaración de los deudores y de las deudas pendientes, lo que dice mucho del orden de prioridades de este importante mercader.

Sebastián de Ocampo quiso ser enterrado en Sevilla, en la iglesia de San Sebastián, allá en el campo de Tablada, ${ }^{24}$ y para ello dispuso con esa pasión de ultratumba, tan usual en esta época, todos los detalles de su sepultura y entierro. Como poderoso hombre de negocios designó un lugar preferente en aquella iglesia: justo delante del altar mayor en una sepultura de bóveda, cubierta por una losa de mármol blanco, del tamaño de su estatura, ornada de la siguiente forma: «y se ponga en ella un letrero que

23 ¿Quién era este misterioso Juan de Ledesma? Nos hubiera gustado despejar esta incógnita, pues nos habría permitido acercarnos aún más al círculo inmediato de Sebastián de Ocampo, pero en el documento en cuestión sólo se dice de él que era vecino de Sevilla. ¿Se trataba del mismo Juan de Ledesma, el maestre de «la Zabra», embarcación de la que era armador el mismo Nicuesa, que en 1509 viajó junto al flamante gobernador de Veragua desde Sevilla a Santo Domingo y luego de acompañarlo a la Tierra Firme regresó a la capital hispalense? Véase Mena (en prensa) y también AGI, Patronato, 150, 4, 1 «Información de méritos y servicios de Diego Fernández o Hernández, vecino de Sevilla que pasó a la Tierra Firme en 1509 con Nicuesa». Sevilla, 5 de abril de 1531. Ha sido publicada por Medina, 1913, II, 351 y siguientes: véase «Declaración del testigo Juan de Ledesma».

24 Hoy parroquia de San Sebastián en el conocido barrio sevillano de «El Porvenir». 
diga: aquí yace Sebastián de Ocampo, que Dios perdona, y en medio de éste las armas de San Francisco, que sea un escudo con las cinco llagas de nuestro Señor Jesucristo, y a la redonda un cordón de San Francisco». Y en señal de humildad, para este trascendental momento elige como mortaja una de las más preferidas en el mundo cristiano durante siglos: el hábito franciscano.

En el testamento de cualquier hombre de alcurnia no podía faltar la institución de una o varias capellanías: fundación religiosa mediante la cual se imponía la celebración de un cierto número de misas anuales por parte de un capellán, el cual solía ser elegido por el propio testador. Como era de prever, Sebastián de Ocampo dispuso también en su testamento la fundación de una capellanía en la citada iglesia de San Sebastián, dotándola con la generosa suma de mil pesos de oro, al tiempo que nombraba como capellán perpetuo de la misma al clérigo Francisco Bernal, estableciendo un orden de sucesión en la capellanía, primero en Pedro Romes, (hijo de su buen amigo el curtidor Juan Romes) y luego en Francisco Guillén. Al cuidado de la citada capellanía y como patronos perpetuos de la misma eligió al prior del monasterio de San Jerónimo de Buenavista y a los priostes del convento y hospital de San Sebastián.

\section{Los herederos. El círculo familiar y afectivo de Sebastián de Ocampo}

El testamento de Ocampo constituye una fuente inapreciable para descubrir los verdaderos afectos, los amigos más cercanos y el linaje familiar, tan desconocidos hasta ahora, a los que el finado transmite una buena parte de sus bienes patrimoniales. Por supuesto son sus hijos naturales: Gonzalo, Simón y María a los que primero dedica su atención. Se aprecia que apenas los conoce, que guarda con ellos una relación muy distante. Acaso le han llegado noticias muy lejanas de cómo han crecido o a qué se dedican, pero no recuerda la edad de sus hijos, ni siquiera sabe si su padre Pedro Hernández, a quien deja como heredero universal de todos sus bienes, vive o ha fallecido ya. Al mayor, Gonzalo de Ocampo, lega cien ducados, como al resto de sus hermanos, pero lo beneficia, además, con «una heredad de cañaverales y tierra de regadío que yo tengo en la dicha isla de la Gomera en el valle del Gran Rey». A Simón, de madre para nosotros desconocida y el único que reside en las Indias, cien ducados de oro. A su 
hija María, que vive en Tenerife, le concede la misma cantidad, pero en concepto de dote y con el requisito indispensable que case con un tal Diego de Arce. Una vez recompensada su prole, Sebastián de Ocampo destina las restantes mandas a sus familiares más cercanos: en primer lugar se observa un trato muy especial con su primo, el gobernador de la Gomera Alonso de Ocampo, pues lo equipara en el caudal hereditario con el mayor de sus hijos, entregándole, además de los consabidos cien ducados, otra importante finca del Valle del Rey, que posee en la isla de la Gomera, llamada «El Prioral», situada justo enfrente de la que lega a su hijo Gonzalo, haciendo constar que «la cual dicha heredad yo hube en repartimiento de mi vecindad». En uno de sus codicilos posteriores reforma esta manda al disponer que su primo el gobernador entregue dos mil maravedís del caudal hereditario a una cierta Isabel Pérez que seguramente debía residir en Las Canarias.

Otras mandas transmiten el afecto y agradecimiento sincero que Sebastián de Ocampo reconoce por la familia de su primo Alonso de Noya. En especial por Inés Romes, esposa de éste y enfermera solícita en los últimos días de Sebastián. A ella deja cinco mil maravedís, haciendo constar que desea recompensarla «por el mucho amor que le tengo y muchas honras y buenas obras que me ha hecho en mi enfermedad». Y no contento con este legado le añade más adelante lo procedido de los beneficios de cierta operación comercial de exportación de cueros, aún no resuelta, a cargo de la sociedad formada por el mismo Ocampo y el curtidor Juan Romes, padre de la citada Isabel. A la hija del matrimonio Noya, Beatriz, a la que conocía desde que era una niña, transformada ya en moza de edad casadera, lega veinticinco ducados, haciendo constar que es «para ayuda de su casamiento por el mucho amor que le tengo». Y por último, a su primo Alonso de Noya, a quien nombra junto al factor de la Casa de la Contratación, Pedro de Isásaga, como albacea testamentario de todos sus bienes al tiempo que le obsequia con «una mi mula pardilla que yo tengo enfrenada y ensillada; la cual le mando graciosamente por el mucho amor que le tengo y muchas honras y buenas obras que de él he recibido». Otras mandas de menor interés histórico están destinadas a recompensar los servicios prestados por algunos servidores de Ocampo, entre ellos un fiel esclavo, respecto al cual Ocampo manifiesta su voluntad de que en un futuro pueda ser liberado, o bien a obras caritativas: a ellos les entrega diversas prendas de vestir siguiendo una costumbre muy enraizada en la época. 


\section{Socios y redes comerciales. Los negocios de un indiano}

Ya lo decíamos más atrás: lo poco que se conoce de Sebastián de Ocampo ha llevado a los historiadores a ubicarlo en el lejano limbo de los primeros exploradores de la geografía americana, sobre todo a raíz de su expedición a la isla de Cuba de tan dudosos resultados, como ya vimos. Sin embargo, en su testamento sevillano se dibuja una figura mucho más compleja y polifacética que la de un simple explorador. Nos descubre sobre todo a un hacendado, que se dedica en Canarias al cultivo del azúcar, ${ }^{25}$ cuyo producto seguramente exporta a Santo Domingo para satisfacer la demanda de los colonos, mientras la isla transita con decisión desde la economía del oro a la del trapiche; a un desahogado representante del comercio atlántico, que goza de excelentes contactos en sus negocios, e incluso a un cambiador relacionado con operaciones crediticias en Sevilla y en las Indias. Cambiador y mercader a un mismo tiempo: no debe sorprendernos. En estos tempranos años resulta difícil discernir entre unos y otros, porque los hombres de la Carrera lo mismo actúan como banqueros que realizando importantes operaciones crediticias de índole mercantil que los convierten también en mercaderes de pleno derecho. ${ }^{26}$

Aquí, en la capital hispalense, se beneficia de su amistad con el factor de la Casa de la Contratación, el vasco Pedro de Isásaga, ${ }^{27}$ a quien —recordemos- nombra incluso albacea de todos sus bienes, y seguramente se relaciona en cuestiones de negocio. Al menos en una ocasión, que sepamos,

25 Véase el apéndice de este trabajo : «Y mando a cada uno de mis albaceas por el trabajo que han de tomar en cumplir mi ánima, a cada uno de ellos diez pesos de oro y más diez arrobas de azúcar blanco de las dichas mis heredades que yo tengo en la dicha isla de la Gomera...» (686r.).

26 Bernal, 1992, 165.

27 Ernesto Schäfer, 1935, no lo menciona en su famosa obra dedicada al Consejo de Indias. Desconocemos, por tanto, el periodo exacto en el que ocupó el cargo de factor (¿interino?) de la Casa de la Contratación. Por su apellido, sin duda de origen vasco, cabe sospechar que podría guardar algún parentesco con el comendador Ochoa de Isásaga, factor de la citada institución entre 1509 y 1518 . En 1515 hay constancia de que Pedro de Isásaga seguía al frente de la Casa. Una Real Cédula dirigida a Sancho de Matienzo tesorero de la Casa, disponía que entregase 15.000 maravedís a Pedro de Isásaga, factor, «que ha de gastarlo en ciertas cosas del real servicio y de los cuales no le ha de tomar cuenta». Valladolid, 20 de enero de 1515. AGI, Indiferente, 419. Tres años más tarde lo encontramos dispuesto a viajar a las Indias: Real Cédula a Pedro de Isásaga ordenándole se prepare para ir a Indias lo más pronto posible, con la misión de tomar las cuentas a los oficiales y personas que tienen cargo de la hacienda de S.M. en La Española, San Juan, Cuba y Jamaica, por lo que se le señalará buen salario. Zaragoza, 2 de septiembre de 1518. Años después repite esta misión como capitán de una flotilla de cinco barcos que recorre las Antillas recaudando la hacienda del rey. Real Cédula a los oficiales de la isla Española, a Diego Velázquez en Cuba y a Francisco Garay en Jamaica para que colaboren con Isásaga. Pamplona, 22 de octubre de 1523. AGI, Indiferente, 420. 
presta al «hacedor» de la Casa treinta ducados de oro mediante la correspondiente carta de pago o albalá. El de Isásaga no constituye, desde luego, un caso excepcional: resulta sobradamente conocido que los funcionarios de la Contratación se implicaron abiertamente en la Carrera de las Indias como agentes y armadores y que esta práctica estuvo muy extendida durante los primeros años de la vida de la institución, hasta 1522 en que fue prohibida. ${ }^{28}$

En Santo Domingo, a donde traslada su vecindad en los años de madurez, conocía a todos los personajes más importantes de la isla, habiendo participado con muchos de ellos, incluso con el efímero gobernador de Veragua, Diego de Nicuesa, de tan desgraciado final, ${ }^{29}$ en operaciones crediticias. De ello quedó constancia en su testamento. En efecto en una de sus cláusulas Sebastián de Ocampo asume una deuda de 30 castellanos de oro, cantidad que había anticipado en nombre de Diego de Nicuesa a un tal Antonio Italiano, probablemente cuando aquel preparaba su expedición a la Tierra Firme:

A (Antonio) Italiano, difunto que Dios haya, treinta castellanos de oro, los cuales me obligué a dar y pagar por Diego de Nicuesa, capitán que fue de Tierra Firme; por ende, mando que si los herederos del dicho Antonio Italiano, $\mathrm{u}$ otra cualquier persona por ellos, no hubiere cobrado los dichos treinta castellanos del dicho Diego de Nicuesa o de sus bienes y constare haber hecho contra él y contra sus bienes todas las diligencias que el derecho requiere, que en tal caso, si las hubieren hecho, le paguen de mis bienes... y doy recurso a mis herederos para los cobrar de cualesquier bienes que del dicho Diego de Nicuesa hayan quedado.

Allí en La Española también se protege las espaldas estrechando lazos mercantiles con uno de los funcionarios más influyentes de aquellos años. En efecto, disfruta de una compañía comercial nada menos que con el poderoso funcionario aragonés Miguel de Pasamonte, incondicional amigo del secretario real Lope de Conchillos, quien desde su llegada a La Española en 1509 como tesorero del rey maneja a su antojo el gobierno de la isla, apoyado en una amplia e influyente camarilla. ${ }^{30}$ Así lo declara en

28 Antonio Acosta, 2003, 341-374, resume muy bien los conflictos derivados de la presencia de oficiales-comerciantes en el interior de la Casa de la Contratación y cómo ello afectó a la gestión interna de la institución.

29 Las Casas, 1957, II, 418-431. Tras ser expulsado de la colonia del Darién, desapareció en marzo de 1511 en el mar Caribe, donde en una nao averiada y con los pocos que permanecieron fieles fue abandonado por la mayor parte de su hueste, capitaneada en su sublevación por Juan de Zamudio y por el gran hostigador de la colonia: Vasco Núñez de Balboa.

30 La figura del tesorero Miguel de Pasamonte y de la camarilla «pasamontista» creada a su alrededor está bien documentada en la obra de Manuel Giménez Fernández, 1960, I, 125 y siguientes. 
uno de los párrafos de su codicilo, en el que hace constar que el objeto de la citada sociedad, que tiene por factor a Francisco de Cisneros, no era otro que «la provisión a la Tierra Firme». ¿Era esa la razón que lo lleva a viajar al Darién en 1512, poniéndolo en contacto con Balboa?

Confieso por decir verdad a Dios y al mundo y guarda y salvación de mi ánima que yo tengo en compañía de Miguel de Pasamonte, tesorero de su Alteza, y de sus hacedores del rey y de los oficiales de Su Alteza que están en las dichas Indias cierta compañía de la provisión que hicimos a Tierra Firme de la cual es factor Francisco de Cisneros, y me resta debiendo de la dicha compañía cien castellanos, los cuales son de lo procedido y principal de la dicha mercadería, los cuales cien castellanos han de cobrar de todos los que en ello tuvieron parte que son los sobredichos.

Además del factor Isásaga y del tesorero Pasamonte, nuestro mercader gallego se sirve en Sevilla para sus negocios de una sólida red de apoyos, gestada casi toda ella en el reducido marco de su círculo familiar. En primer lugar, de un hombre de toda su confianza y muy querido: su primo, el mercader Alonso de Noya, a quien confía en su testamento la administración de su legado y dedica una de sus mandas: A Alonso de Noya, mi primo y mi albacea... por el mucho amor que le tengo y muchas honras y buenas obras que de él he recibido.

$\mathrm{Al}$ tiempo que pone en orden los asuntos pendientes entre ambos: por un lado, le reclama la deuda pendiente de cincuenta ducados de oro y, por otro, los gastos generados en su servicio: en primer lugar, 1.000 maravedís «que gastó por mí en ciertas cosas, y más le debo otros dos ducados que también dice que gastó por mi: mando que le sean pagados y remítolo a lo que él declarare que le debo que le sea pagado... Y asimismo, mando que todos los maravedís que Alonso de Noya, mi primo y mi albacea, declarare en su conciencia y juramento que sobre ello haga que yo le debo, según él lo diere por su cuenta con el dicho juramento, que todo le sea pagado de mis bienes».

Otro de los factores de Ocampo en la capital hispalense también guarda parentesco con su primo: es el curtidor Juan Romes, por más señas suegro de Alonso de Noya, ya que - recordemos - éste estaba casado con una hija del curtidor, llamada Isabel Romes. Con aquél comparte una compañía comercial dedicada al negocio de los cueros, seguramente para traficar con América, con una base patrimonial de 300 ducados de oro, cuyos beneficios reclama ahora en su testamento como legado de sus herederos:

Y confieso... que Juan Romes, curtidor, vecino de esta ciudad de Sevilla, en la collación de San Llorente, me debe trescientos ducados de oro que en mi testamento ten- 
«AQUÍ YACE SEBASTIÁN DE OCAMPO, QUE DIOS PERDONA»

go declarados que Juan de Oñate por mi mandado le prestó, y que estos dichos trescientos ducados de oro confieso que fueron para que el dicho Juan Romes los comprase de cueros, los cuales tiene comprados para que en compañías le comprase y vendiese, y que la ganancia que en ello hubiese, la partiésemos de por medio, que él hubiere la mitad y yo la otra mitad.

Mientras Ocampo se debate entre la vida y la muerte, el curtidor Juan Romes y su hija Isabel atienden solícitos a Sebastián de Ocampo. En ausencia de su primo Alonso de Noya, en cuya casa se aloja, le procuran toda clase de cuidados, seguramente buscan al mejor galeno de Sevilla y los mejores remedios para el enfermo, todo lo cual genera una serie de gastos que Sebastián se ve obligado a reconocer:

Y mando que por cuanto Juan Romes, curtidor, vecino de esta ciudad de Sevilla, ha gastado en mi enfermedad alguna contía de maravedís por mi mando que todo lo que él declare en su conciencia que hubiere gastado, le sea descontado, recibido en cuenta de una deuda que me debe de trescientos ducados, que en mi testamento tengo declarados.

Un interesante personaje suscita especialmente nuestra atención. Se trata del platero Juan de Oñate, un artífice de reconocida reputación en la capital sevillana, cuya actividad polifacética en la Carrera de Indias, bien ajena a su profesión artística, no nos resulta desconocida. ${ }^{31}$ Los Oñate conformaban una prolífica saga de plateros, originarios, seguramente, de la localidad navarra del mismo nombre, pero muy activos por Castilla y Sevilla a lo largo del siglo XVI. Desde la capital hispalense, donde se establecieron desde fines del siglo XV y donde fundaron una importante compañía mercantil en 1516 con vistas al comercio ultramarino, los plateros Juan, Martín y Pedro de Oñate, que pertenecían a una misma familia, desarrollaron una intensa actividad en la Carrera de Indias, especialmente Juan que participó activamente en diversos negocios (mercader y socio comanditario, comprador de oro, fiador de mercancías y pasajeros, acreedor de pilotos y maestres de naos, prestamista, etc.), sin moverse de Sevilla en donde residía entre 1497 y 1526, aunque fue Pedro el único que pasó a América en diversas ocasiones. No sabemos en qué preciso momento Sebastián de Ocampo entró en contacto con el emprendedor artista Juan de Oñate. Seguramente supo de sus lucrativas actividades a través del factor

31 Sobre la actividades de esta familia de plateros en la Sevilla del Quinientos puede ampliarse información en los documentados trabajos de $M^{\mathrm{a}}$ Carmen Heredia Moreno, 1996, 555-566 y M. ${ }^{\mathrm{a}}$ Jesús Serrano Sanz, 2010, 717-738. 
de la Casa de la Contratación Pedro de Isásaga, pues con esta institución el platero mantenía vínculos muy estrechos. Está documentado que entre 1511 y 1514 Oñate, que ostenta el cargo de platero de la catedral de Sevilla, se concierta al menos en tres ocasiones con los oficiales de la Contratación para comprar todo el oro que venía de las Indias para las arcas reales, pagándolo según el precio previamente estipulado en el contrato y que es depositario de gruesas cantidades que otros mercaderes le confían para asuntos mercantiles y bancarios diversos. Uno de sus agentes es nuestro mercader Sebastián de Ocampo con quien Juan de Oñate se vincula en calidad de apoderado-prestamista en negocios bancarios.

y declaro, por decir verdad a Dios y al mundo y guardar salud de mi ánima, que el dicho Juan de Oñate los dio (600 ducados) a las dichas personas prestados por mi mandado y que de ellos tiene en su poder el dicho Juan de Oñate cédulas y albaláes, de cada uno de la contía que recibió.

\begin{tabular}{|c|c|c|}
\hline \multicolumn{3}{|c|}{ Acreedores de Sebastián de Ocampo } \\
\hline Nombre & Concepto & Valor \\
\hline $\begin{array}{l}\text { Antonio Italiano (por } \\
\text { Diego de Nicuesa) }\end{array}$ & & 30 pesos \\
\hline $\begin{array}{l}\text { Fernando de Mesa, } .^{\circ} \\
\text { de Buenaventura (¿La } \\
\text { Española?) }\end{array}$ & & 4 pesos \\
\hline Diego Morales & $\begin{array}{l}\text { Diezmo de la miel } \\
500 \text { montones de yuca } \\
500 \text { montones de } \\
\text { ¿cazabes? } \\
2 \text { camisas } \\
\text { Unos zapatos }\end{array}$ & \\
\hline Alonso de Noya & & $\begin{array}{l}1.000 \text { maravedís } \\
2 \text { ducados }\end{array}$ \\
\hline $\begin{array}{l}\text { Juan Romes, curtidor } \\
\text { de Sevilla }\end{array}$ & $\begin{array}{l}\text { Gastos causados por la } \\
\text { enfermedad de Sebastián } \\
\text { de Ocampo }\end{array}$ & \\
\hline
\end{tabular}


En estos tempranos años, en ausencia de una red bancaria debidamente organizada, el capital comercial privado fluye por los vericuetos más insospechados. Ocampo confiesa en su testamento que tiene depositados en manos del platero Oñate 600 ducados de oro para operaciones crediticias. ${ }^{32}$ Reconoce a sus deudores: los citados Juan Romes, Pedro de Isásaga y Alonso de Noya, además de un vecino de Alanís, llamado Juan de León y encomienda a su apoderado Oñate el cobro de los diferentes créditos, así como de las deudas pendientes en las Indias o en cualquier otro lugar, que servirán para hacer frente tanto a la dotación de mil ducados con los que ha dotado a su capellanía, como a satisfacer el legado de sus herederos y los cuarenta ducados por los gastos generados en la negociación de los intereses de Balboa, que Ocampo encomienda en trance de muerte a su primo Alonso.

Desgraciadamente el legado testamentario de Sebastián de Ocampo omite con frecuencia el volumen concreto en cifras de las deudas pendientes de cobro, así como los beneficios de las operaciones mercantiles citadas, lo que nos impide ponderar con exactitud el nivel de la fortuna de nuestro personaje. A ello se añade otro factor de complejidad: las diferentes unidades monetarias empleadas por el testador y sus particulares equivalencias: castellanos, ducados y pesos de oro. ${ }^{33}$ Pero, por lo que se aprecia, no cabe la menor duda de que el mercader Ocampo disfrutaba de una situación económica más que boyante. En efecto, un cálculo aproximado de las cantidades adeudadas a su favor, superior a los mil ducados, frente a las insignificantes deudas pendientes de saldar por Ocampo, así como las rentas de sus dos sociedades mercantiles y el valor de sus haciendas en la isla de la Gomera arrojan un saldo favorable que no desmerece al de otros acomodados comerciantes indianos. Ello permitirá a este indiano enriquecido - llegada la hora de su muerte - invertir parte del capital acumulado en esta vida con la fundación - recordemos - de una capellanía de misas por su eterno descanso de mil ducados de oro, con la seguridad de que con este acto seguía acumulando beneficios para el más allá.

32 Por lo que sabemos era ésta una práctica habitual del platero sevillano. Ma Carmen Heredia, 1996, 563, nos informa cómo en 1514 Juan de Oñate figura ya como socio del cambiador sevillano Francisco Morilla para operaciones bancarias. Dos años más tarde consta por una carta de pago que el platero ha recibido en depósito 600 ducados de oro del mercader vizcaíno Pedro de Vergara, cantidad que le reintegra diez años más tarde.

33 Al peso de 450 maravedís se le llamó castellano, 5 castellanos de a 450 maravedís $=6$ ducados de 375 maravedís, pero Sebastián de Ocampo advierte que maneja un valor diferente de 400 maravedís el peso: «seiscientos ducados de oro, los cuales son de los seiscientos pesos de oro míos que yo le dejé en su poder en guarda, razonados cada peso a cuatrocientos maravedís». Céspedes del Castillo, 1996, I, 52. 


\begin{tabular}{|c|c|c|}
\hline \multicolumn{3}{|c|}{ Deudores } \\
\hline Nombre & Concepto & Valor \\
\hline Diego de Nicuesa & & 30 castellanos \\
\hline $\begin{array}{l}\text { Juan de Oñate, platero } \\
\text { de Sevilla }\end{array}$ & $\begin{array}{l}\text { Depósito: } \\
\text { Préstamo 1. A Juan } \\
\text { Romes, curtidor de } \\
\text { Sevilla: } 300 \text { ducados } \\
\text { Préstamo } 2 . \text { A Pedro de } \\
\text { Isásaga, factor de la Casa } \\
\text { de la Contratación: } \\
30 \text { ducados } \\
\text { Préstamo 3. A Alonso de } \\
\text { Noya: } 50 \text { ducados } \\
\text { Préstamo 4. A Juan de } \\
\text { León, v. }{ }^{\circ} \text { de Alanís: } \\
18 \text { ducados }\end{array}$ & 600 ducados \\
\hline $\begin{array}{l}\text { Juan de León, v. }{ }^{\circ} \text { de } \\
\text { Alanís }\end{array}$ & $\begin{array}{l}20 \text { arrobas de vino, } \\
\text { a } 85 \text { mrs./arroba }\end{array}$ & 1.700 maravedís \\
\hline Bachiller Moreno & $\begin{array}{l}\text { De lo que resta «de cierta } \\
\text { hacienda que le vendí en } \\
\text { la isla Española» por } \\
180 \text { pesos }\end{array}$ & 100 pesos \\
\hline $\begin{array}{l}\text { Miguel de Pasamonte, } \\
\text { tesorero real }\end{array}$ & $\begin{array}{l}\text { Beneficios de una } \\
\text { sociedad comercial }\end{array}$ & 100 castellanos \\
\hline $\begin{array}{l}\text { Juan de Llanes, v. }{ }^{\circ} \text { de } \\
\text { Sevilla }\end{array}$ & Venta de un caballo & 9 ducados \\
\hline $\begin{array}{l}2 \text { vecinos de la isla de } \\
\text { Cuba (uno llamado } \\
\text { Ordaz) }\end{array}$ & & 40 castellanos \\
\hline $\begin{array}{l}\text { Juan Romero, de La } \\
\text { Serena, ya difunto }\end{array}$ & & 82 pesos \\
\hline $\begin{array}{l}\text { Bernardino de Tejada, } \\
\text { v. }^{0} \text { de Toledo }\end{array}$ & & 26.000 maravedís \\
\hline
\end{tabular}

34 «el cual tenía un hermano en las Indias que se llamaba Serrano». 


\section{Apéndice}

\section{TESTAMENTO DE SEBASTIÁN DE OCAMPO ${ }^{35}$}

Sevilla, 25, junio, 1514

AHPS, 2209, Oficio IV, Escribanía de Manuel Segura, 1514-2º

[693v.] (Encabezamiento ilegible)... Yo Sebastián Docampo, hijo de Piero Hernández de Tuy, natural de la ciudad de Tuy, estante que ahora estoy en esta ciudad de Sevilla, enfermo del cuerpo e sano de la [...] voluntad e en mi seso e acuerdo e entendimiento e en muy buena e cumplida memoria, tal cual Dios, nuestro señor quiso e tuvo por bien de me la querer dar, e creyendo firme e verdaderamente en la Santísima Trinidad comprendida Padre e Hijo e Espíritu Santo, tres personas e un solo Dios verdadero, bien así como todo fiel e verdadero cristiano debe tener e creer, e yo así lo creo e tengo, e temiéndome de la muerte, que es cosa natural, de la cual persona del mundo no puede escapar e codiciando e habiendo voluntad de poner la [...] Dios, nuestro señor, [...] haya misericordia e piedad de ella e la quiera redimir e salvar e llevar a su santo reino celestial donde glorifique e alabe su divina majestad. Por ende, otorgo e conozco que hago e ordeno este dicho mi testamento e las mandas e cláusulas en él contenidas de mis bienes en que hago y ordeno, así en hecho de mi cuerpo como de mi ánima, por mi ánima salvar e mis herederos pacificar acerca de las deudas que yo debo, digo y declaro por descargo de mi conciencia que son las siguientes: a Italiano, difunto que Dios haya, treinta castellanos de oro, los cuales me obligué a dar y pagar por Diego de Nicuesa, capitán que fue de Tierra Firme; por ende, mando que si los herederos del dicho Antonio Italiano, u otra cualquier persona por ellos, no hubiere cobrado los dichos treinta castellanos del dicho Diego de Nicuesa o de sus bienes y constare haber hecho contra él y contra sus bienes todas las diligencias que el derecho requiere, que en tal caso, si las hubieren hecho, le paguen de mis bienes [693r.]... (faltan varios reglones en cabeza del folio) y doy recurso a mis herederos para los cobrar de de cualesquier bienes que del dicho Diego de Nicuesa hayan quedado. Y asi-

35 Dada la extensión del documento original y de los codicilos y otras cartas que lo acompañan, hemos considerado oportuno abreviarlos, haciendo caso omiso de fórmulas estereotipadas o de fragmentos que carecen de suficiente interés. Lo indicamos con el uso de cursivas entre corchetes. Por otro lado, algunos folios del documento se encuentran muy dañados, haciendo imposible la lectura de algunas palabras o frases completas. En tal caso, nos servimos del uso de puntos suspensivos entre corchetes. 
mismo confieso que debo a Fernando de Mesa, vecino de la Buenaventura, cuatro pesos de oro por una albalá mío; mando que se los paguen y declare que él me tiene en prenda de ellos un caballo morcillo ensillado: mando que lo cobren de él, si el dicho caballo estuviere vivo y si no, cobren los aparejos de él y le paguen la dicha deuda. Item, confieso que debo a Diego de Morales el diezmo de miel y quinientos montones de yuca y de quinientos montones de cares (¿cazabes?), y más le debo dos camisas de Ahetí (Haití), a veinte reales cada una, y unos zapatos en siete reales y cuatro pesos de oro que me dio por él Diego González: mando que se lo paguen todo. Item, digo y declaro por descargo de mi conciencia y por decir verdad a Dios y al mundo y guardar salud de mi ánima que yo vendí un esclavo a Alvarado, vecino de Santo Domingo, que es en las dichas Indias, el cual se llama García, que es natural de Macao, que ahora tiene un criado del alcalde Rodrigo de Alburquerque, el cual ahorró el comendador mayor, gobernador que era en la isla Española. Y yo, por descargo de mi conciencia, digo y mando que lo compren porque esta es mi voluntad de lo dejar libre, el cual yo vendí por treinta pesos de oro, éstos mando que den por él, y si costare más, que el dicho esclavo los pague y sirva por ellos.

Y estas son las deudas que yo confieso que me deben: primeramente me debe el bachiller Moreno cien castellanos de oro de cierta hacienda que le vendí en ciento y ochenta pesos de oro y de resto de ella me quedó a deber los ciento; y mando que porque traen pleito en la dicha isla, en mi nombre, sobre ellos, que si por averiguación diere cincuenta pesos que los reciban y de los otros cincuenta [692 v.] cobren de quien me lo deba.

Y estas son las mandas que yo mando: primeramente mando mi ánima a Dios e a Santa María e a todos los santos e santas de la corte del cielo, que sean intercesores a mi redentor Jesucristo por mi ánima que la quiera perdonar. E cuando el finamiento de mi acaeciere, mando que mi cuerpo sea sepultado en la iglesia e casa del señor San Sebastián, que es fuera y cerca de esta ciudad de Sevilla en el campo de Tablada, y que mi sepultura sea delante del altar mayor de la dicha iglesia, y que hagan una sepultura de bóveda y encima de ella me pongan una piedra blanca de mármol, de mi estatura, y se ponga en ella un letrero que diga: aquí yace Sebastián de Ocampo, que Dios perdona, y en medio de éste las armas de San Francisco, que sea un escudo con las cinco plagas (sic) de nuestro redentor Jesucristo, y a la redonda un cordón de San Francisco; y mando que me entierren en el hábito del señor San Francisco...y mando a la obra de San Marcos de esta ciudad de Sevilla por honra de los sacramentos que de la dicha iglesia he recibido y espero recibir [692] doscientos maravedís, e mando a la Santa Cruzada, un real de plata, e mando a las órdenes de la Santa trinidad e de Santa María de la Merced de esta ciudad para ayuda a la redención de los cristianos que están cautivos en tierras de moros enemigos de nuestra santa fe católica, a cada una orden un real de plata, e mando a la obra de Santa María de [...] Sevilla por ganar los perdones que 
en ella son, otro real de plata. E mando que para mi enterramiento se busquen treinta clérigos togados que acompañen mi cuerpo e en todos me digan misa el día de mi entierro en la dicha iglesia de San Sebastián. E además de las misas que ellos dijeren, mando que digan el dicho día de mi enterramiento, estando mi cuerpo presente, una misa de réquiem cantada, e en todas las dichas misas sean ofrendadas con su ofrenda de pan e vino e cera [...] cumplieren. E mando que les den a los dichos clérigos, así por decir las dichas misas como por acompañar mi cuerpo, toda la limosna que se acostumbra dar. E mando asimismo que acompañe mi cuerpo la cofradía de la Misericordia nueva de esta ciudad, que le den dos castellanos de oro. E mando que después del dicho día de mi enterramiento me hagan los nueve días y cabo de año y estos me los hagan en la dicha iglesia de San Marcos en tres días primeros siguientes después del día de mi enterramiento e que en cada uno de ellos me digan tres misas rezadas y en fin de ellos me digan otras tantas misas e oficios como el día de mi enterramiento. E que sean todas ofrendas de pan e vino e cera la que cumplieren e den por las dichas las limosnas acostumbradas. E mando que de mis bienes se compren quinientos maravedís de tributo e censo perpetuo en cada un año para siempre jamás, los cuales dichos quinientos maravedís de dicho tributo e censo mando que se den a la dicha iglesia e casa de San Sebastián donde mi cuerpo ha de ser sepultado para que de dicho tributo me hagan decir los priostes e cofrades de la dicha cofradía de San Sebastián que ahora son o fueren de aquí en adelante para siempre jamás una fiesta de Nuestra Señora de su santa Concepción e que se diga solemnemente un día en la tarde sus vísperas cantadas e otro día siguiente su misa cantada con diácono e sus diáconos e presbítero de la dicha iglesia, e salgan con su responso e agua bendita sobre mi sepultura. [Al margen: Fundación de capellanía] E por esta manda de mi testamento, instituyo e mando que se me diga e ante una capellanía perpetua [...] para siempre jamás en la dicha iglesia y casa de San Sebastián, donde mi cuerpo fuese sepultado, en la cual mando que me digan en cada un mes perpetuamente veinte misas rezadas, dentro en la dicha iglesia por mi ánima e de mis difuntos e antecesores, e en fin de cada misa, el capellán que la dijere salga con su responso rezado sobre mi sepultura. E doto e mando para la dicha capellanía porque muy bien se pueda decir e cantar e quede memoria perpetua en la dicha iglesia para siempre jamás de esta dicha institución, que yo en ella fundo, mil ducados de oro, que montan trescientos setenta y cinco mil maravedís, [691r.] de los cuales mando que se compren tributos e posesiones e renta perpetua para siempre jamás la que ellos bastaren e que sea segura e bien parada e en buenas posesiones e que la renta e tributos que de los dichos mil ducados se compraren, como dicho es, mando que se distribuyan e gasten en la dicha mi capellanía e en pro e utilidad de la dicha iglesia en esta manera: primeramente, que de la dicha renta se de e pague [...] para siempre jamás al capellán que dijere e cantare la dicha mi capellanía, catorce mil maravedís, los cuales el dicho capellán haya e cobre de las personas que se compraren los dichos tributos para su pro- 
veimiento e alimentos, a los plazos e según e de la manera que fueren obligados a los pagar, porque con ellos él se pueda mejor proveer e sustentar e rogar a Dios por mi ánima, e de lo restante que sobrare de la dicha renta, mando que se dé a un patrón que yo señalare en esta mi dicha capellanía mil maravedís en cada un año para siempre jamás por el cargo que él y sus descendientes han de tener en [...] las posesiones dotadas a la dicha capellanía e tributos que así se compraren, como dicho es, e en ver si se dice e canta de la forma e manera que yo la dejo dotada e mandada, como dicho es, e para que compela a los que dejo el cargo de ello que lo hagan e cumplan, e de lo restante que sobrare mando que se compren luego dos casullas, la una de damasco blanco con sus cenefas de carmesí e con todo lo a ella necesario de la misma manera para que con ellas se me digan las dichas fiestas de nuestra Señora perpetuamente e todas las otras fiestas solemnes e principales que en cada un año se dijeren... (manda comprar, además, un cáliz de plata con su patena y otros ornamentos) para la casa e iglesia de San Sebastián, a fin de aumentar sus bienes... y para que la dicha casa se pueda aumentar e edificar todo lo que en ella falta para se acabar. E nombro por mi capellán perpetuo de la dicha mi capellanía, para que la diga y cante todos los días de su vida, al bachiller Francisco Bernal, clérigo presbítero, vecino de esta ciudad de Sevilla en la collación de Santa María, que ahora reside en compañía de Polo de Grimaldo, canónigo de la santa iglesia catedral de Sevilla. Y mando que después de los días de la vida del dicho bachiller Francisco Bernal, suceda en la dicha mi capellanía y sea mi capellán perpetuo en ella todos los días de su vida Pedro Romes, hijo de Juan Romes, curtidor, vecino de esta ciudad de Sevilla en la collación de San Lorenzo, y después de los días de su vida del dicho Pedro Romes mando que suceda en la dicha capellanía y sea mi $[690$ v.] capellán perpetuo en ella Francisco Guillén, presbítero, capellán y beneficiado de la dicha iglesia de San Marcos y vecino de esta dicha ciudad en la dicha collación de San Marcos...y después de los días de las vidas de los dichos mis tres capellanes que yo así dejo nombrados sucesivamente, como dicho es, que los dichos mis patrones que yo dejo nombrados y señalados en este dicho mi testamento que de yuso serán declarados, juntamente y de una conformidad, nombren capellán perpetuo a la dicha mi capellanía para que la diga y cante todos los días de su vida.

[690r.] [instrucción a los patronos de la capellanía]... [689 v.] Y mando que los dichos mil ducados de oro, que yo dejo dotados para la dicha mi capellanía, como dicho es, que aquellos se cumplan y den y paguen de esta manera: que de ellos de y pague Juan de Oñate, platero, vecino de esta ciudad de Sevilla, seiscientos ducados de oro, los cuales son de los seiscientos pesos de oro míos que yo le dejé en su poder en guarda, razonados cada peso a cuatrocientos maravedís, e lo que sobran de los dichos seiscientos pesos de oro, sacados los dichos seiscientos pesos de oro que yo di a Juan de Oñate, se han dado prestados de ellos, por mi mandado, a Juan Romes, vecino de esta dicha ciudad de Sevilla en la colla- 
ción de San Lorenzo, trescientos ducados de oro; y a Pedro de Isásaga, hacedor de la Casa de la Contratación de las Indias de esta ciudad, treinta ducados de oro; y a Alonso de Noya, mi primo, vecino de esta ciudad, cincuenta ducados de oro; y a Juan de León dieciocho ducados de oro, de los cuales el dicho Juan de Oñate tiene en su poder ciertas prendas de oro del dicho Juan de León, las cuales dichas cuantías de ducados digo y declaro, por decir verdad a Dios y al mundo y guardar salud de mi ánima, que el dicho Juan de Oñate los dio a las dichas personas prestados por mi mandado y que de ellos tiene en su poder el dicho Juan de Oñate cédulas y albaláes, de cada uno de la contía que recibió; y mando que todas las dichas contías declaradas [689 r.] que el dicho Juan de Oñate dio por mi mandado a las dichas personas, como dicho es, las haya y cobre él todas a las dichas personas y de cada uno de ellos, y los recoja y retenga en sí todas para que sean enterados los dichos seiscientos ducados de oro; y para los cobrar, yo le doy poder cumplido bastante, según que de derecho en tal caso se requiere, e mando que sobre los dichos seiscientos ducados de oro que así el dicho Juan de Oñate ha de dar para la dicha mi capellanía, habiendo cobrado lo que así deben los sobredichos, mando que toda la demasía, a cumplimiento de los dichos mil ducados de oro, se cumplan de las dichas deudas que yo confieso que me deben en las dichas Indias de lo primero e mejor parado que de ellos cobrare de manera que entera y cumplidamente se pueda hacer cumplir la dicha mi capellanía de la manera que declarado tengo en este mi dicho testamento. E mando que luego, sin dilación alguna, se comiencen a solicitar las cosas tocantes a la dicha mi capellanía... Y por esta carta de mi testamento nombro por mis patronos perpetuos de la dicha mi capellanía al reverendo padre prior [688 v.] [roto...] del monasterio de San Jerónimo de Buenavista, que es fuera y cerca de esta ciudad de Sevilla [roto...] para siempre jamás; y asimismo a los priostes que son o fueren [roto...] en la dicha casa y hospital de San Sebastián [688 r.] Y mando a Gonzalo de Ocampo, mi hijo natural, e hijo de María de Ocampo, vecina de la isla de la Gomera, cien castellanos de oro y una heredad de cañaverales y tierra de regadío que yo tengo en la dicha isla de la Gomera en el valle del Gran Rey, la cual dicha heredad yo hube de Alonso Prieto, mando que los dichos cien castellanos de oro le sean pagados de las deudas que me deben en las Indias en el dicho mi hijo susodicho, e que él pueda disponer todo lo que quisiere como por cada cosa suya. E mando que luego le sea todo dado y entregado a la dicha María de Ocampo, su madre, si él estuviere en poder de ella, para que todo lo tenga en su poder hasta que él sea de edad para lo tener y administrar todo, y si él fuere de edad para ello, se lo den a él... Y mando asimismo a Simón de Ocampo, mi hijo natural, que ahora está en la isla de San Juan, que es en las Indias del mar océano, otros cien castellanos de oro y que estos se los den asimismo de las deudas que me deben en las dichas Indias. Y mando a Alonso de Ocampo, mi primo, gobernador de la isla de la Gomera, otra heredad que yo tengo en la dicha isla, que se llama 
El Prioral, y que es en el mismo valle del Gran Rey, enfrente de la otra heredad que yo mando al dicho Gonzalo de Ocampo, mi hijo; la cual dicha heredad yo hube en repartimiento de mi vecindad; y asimismo le mando otros cien castellanos de oro al dicho Alonso de Ocampo, mi primo, por el mucho amor que le tengo e por los muchos cargos en que le soy [...], los cuales dichos mil castellanos mando que se le den e paguen de las dichas deudas de las dichas Indias. [687 v.] E mando a Ana García, vecina de esta ciudad en la collación de Santa María, en la Cestería, hija de Diego Sánchez, veinticinco castellanos de oro por cargo en que le soy, los cuales mando que le sean pagados de las dichas deudas de las Indias. E mando a Beatriz, hija de Alonso de Noya, mi primo, otros veinticinco castellanos de oro para ayuda a su casamiento por el mucho amor que le tengo. Y mando a María de Ocampo, mi hija e hija de Margarida Marrana, vecina de la villa de Tenerife, cien castellanos de oro que le sean pagados de mis deudas de las dichas Indias, los cuales le mando por el mucho amor que le tengo, e que les sean dados con cargo y condición que ella se case con Diego de Arce, porque esta es mi voluntad. Y pagado y cumplido este dicho mi testamento... todo lo al que fincare... mando que los haya y herede todos el dicho Pedro Fernández de Tuy, mi padre, al cual yo dejo y establezco por mi legítimo y universal heredero en todo el remanente de los dichos mis bienes. Y si él no fuere vivo, mando que sean mis herederos universales en todo el remanente de todos los dichos mis bienes y derechos y acciones los dichos Gonzalo de Ocampo y Simón de Ocampo, mis hijos, y Alonso de Ocampo, mi primo, a los cuales dejo y nombro por mis herederos universales en todo el remanente de los dichos mis bienes, igualmente, tanto al uno como al otro, y que hayan la dicha herencia demás y allende de las mandas que a cada uno de ellos tengo hechas, como dicho es. [687] Y que la dicha María de Ocampo, mi hija, no tenga más de los dichos cien castellanos de oro que le mando, como dichos es. Y siendo vivo el dicho Pedro Fernández de Tuy, mi padre, al que yo dejo por mi heredero, como dicho es, le ruego y encargo que todos mis bienes que él de mi hubiere y heredare los tenga y goce de dichos mis bienes que así de mí hubiere y heredare los deje a los dichos Gonzalo de Ocampo y Simón de Ocampo, mis hijos, y Alonso de Ocampo, mi primo, para que los hayan y los hereden todos igualmente, como dicho es, tanto el uno como el otro, y así se lo encargo y ruego que lo deje mandado y yo así mando que se cumpla porque todos los dichos mis bienes yo los he ganado por mi persona e industria y trabajo por mar y por tierra ... Y para pagar y cumplir este dicho mi testamento... hago ende mis albaceas para que lo paguen y cumplan... a los dichos Pedro de Isasaga, vecino de esta ciudad de Sevilla en la collación de Santa María, dentro de la Casa de la Contratación, factor que es de la dicha Casa de la Contratación, y Alonso de Noya, mi primo, vecino de esta ciudad de Sevilla, en la collación de San Marcos... Y mando a cada uno de mis albaceas por el trabajo que han de tomar en cumplir mi ánima, a cada uno de ellos diez pesos de oro 
y más diez arrobas de azúcar blanco de las dichas mis heredades que yo tengo en la dicha isla de la Gomera... [fol. 686 v.] Y por esta carta de mi testamento revoco y anulo... Fecha la carta de testamento en Sevilla estando en las casas de la morada del dicho Alonso de Noya, que son en esta ciudad de Sevilla en la collación de San Marcos, domingo, 25 días del mes de junio, año del nacimiento de nuestro Salvador Jesucristo de 1514 años... Y porque no pudo firmar, firmolo por él los testigos que fueron presentes: Pedro Fernández e Cristóbal Díaz e Alonso Guerrero, escribanos de Sevilla.

[686r.] CODICILO. En el nombre del muy alto... yo Sebastián de Ocampo... ratificando y aprobando la carta de testamento... y queriendo añadir algunas cosas cumplideras a descargo de mi ánima y conciencia, por ende, otorgo y conozco que hago y otorgo este mi codicilo en el cual primeramente confieso por decir verdad a Dios y al mundo y guarda y salvación de mi ánima que yo tengo en compañía de [685v.] Miguel de Pasamonte, tesorero de su Alteza y de sus hacedores del rey y de los oficiales de Su Alteza que están en las dichas Indias cierta compañía de la provisión que hicimos a Tierra Firme de la cual es factor Francisco de Cisneros, y me resta debiendo de la dicha compañía cien castellanos los cuales son de lo procedido y principal de la dicha mercadería, los cuales cien castellanos han de cobrar de todos los que en ello tuvieron parte que son los sobredichos. Y asimismo, confieso por decir verdad que tengo en poder de Juan de León, vecino de Alanís, veinte arrobas de vino que yo compré en la dicha villa, a ochenta y cinco maravedís la arroba, y me tiene él en su poder el dicho vino. Y confieso que me debe Juan de Llanes, vecino de Sevilla, nueve ducados de oro de un caballo que le vendí de los cuales tiene hecho un contrato público de deudo ante Bernardo de Ulloa, escribano público de Sevilla. Y mando al dicho Alonso de Ocampo, mi primo, dé a Isabel Pérez, hija de Esteban Pérez, dos mil maravedís y que estos sean de cien castellanos y de una heredad que yo le mando al dicho mi primo Alonso de Ocampo, según en mi testamento se contiene, y que los dichos dos mil castellanos se los dé por cargos en que el dicho Alonso de Ocampo le es, e yo así se lo encargo. E confieso... que Juan Romes, curtidor, vecino de esta ciudad de Sevilla, en la collación de San Llorente, me debe trescientos ducados de oro que en mi testamento tengo declarados que Juan de Oñate por mi mandado le prestó, y que estos dichos trescientos ducados de oro confieso que fueron para que el dicho Juan Romes los comprase de cueros, los cuales tiene comprados para que en compañías e comprase y vendiese, y que la ganancia que en ello hubiese, la partiésemos de por medio, que él hubiere la mitad y yo la otra mitad; por ende, mando que toda la parte de la dicha ganancia que yo en ello había de haber y me había de dar de mi parte, que la haya y se la de a Inés Romes, hija del dicho Juan Romes, mujer del dicho Alonso de Noya, mi primo, los cuales yo le mando por muchos cargos que de ella tengo y buenas [685r.] obras que de ella he recibido. Y confieso que debo a Alonso de Noya mil maravedís que gastó por mí en ciertas cosas, y más le 
debo otros dos ducados que también dice que gastó por mí: mando que le sean pagados y remítolo a lo que él declarare que le debo que le sea pagado. Y confieso que me deben en la isla de Cuba, que es en las Indias del mar océano, dos vecinos de ahí, el uno que se llama Ordaz y el otro su compañero con él de mancomún, cuarenta castellanos de oro por una obligación que me otorgaron ante (en blanco) de Espinosa, escribano público de la dicha isla de Cuba, puede haber quince meses, poco más o menos; y porque yo les mandé con un amigo carta mensajera que diesen y pagasen los dichos cuarenta castellanos a Francisco de Córdoba, vecino de Alanís, mando que si no se les hubiesen dado y pagado al dicho Francisco de Córdoba que el dicho Francisco de Córdoba los haya y cobre para sí. Y confieso que me debe Juan Romero, vecino de Capillas, tierra de la Serena, difunto que Dios haya, ochenta y dos pesos de oro por una obligación y porque el dicho Juan Romero es difunto y yo no tengo certidumbre de la hacienda que dejó, si era suya o no, mando que esto vieren: quedando de él bienes de que buenamente se puedan cobrar los dichos pesos de oro de sus herederos o de otra culquier persona que su hacienda tuviere, mando que se cobren, y si no hubiese dejado hacienda para ello de que buenamente se hayan de cobrar, yo les hago gracia y limosna y suelta de todo ello por amor de Dios; y que todo lo al en el dicho mi testamento contenido ratifico y apruebo... Fecha la carta de codicilo en Sevilla estando en las casas de la morada del dicho Alonso de Noya, lunes, 26 días del mes de junio, año del nacimiento de nuestro Salvador Jesucristo de 1514 años. Y porque no pudo firmar por su enfermedad...

[684v.] CODICILO: En el nombre del muy alto... yo Sebastián de Ocampo... ratificando y aprobando la carta de testamento... y asimismo la carta de codicilo... y queriendo... añadir y acrecentar algunas cosas cumplideras a descargo de mi conciencia, por ende, otorgo y conozco que hago y ordeno esta mi carta de codicilo en la cual confieso y declaro que me debe Bernardino de Texada, hijo de (blanco) Colchero, vecino de la ciudad de Toledo, el cual tenía un hermano en las Indias [684r.] que se llamaba Serrano, veintiséis mil maravedís que pagué por él a Fernando de la Isla, y más me debe diez castellanos de oro que pagué por él como su fiador a Andrés de Haro y tengo de él escritura de gasto la cual tiene en su poder Diego de Torres, fiador de Bernardino de la Isla, que está en las Indias del mar océano, o en poder de Alonso de Ocampo, mi primo: mando que sean cobradas de él; y mando que todas las deudas que me deben en las dichas Indias todas las personas que tengo declaradas en el dicho mi testamento y codicilo se cobren y vengan todas a la Casa de la Contratación, que todo lo que así se cobrare y hubiere, como dicho es, de las dichas deudas lo haya y cobre todo Juan de Oñate, platero, vecino de esta dicha ciudad de Sevilla, en la collación de Santa María, y que teniéndolo él todo en su poder lo que así se hubiere cobrado y cobrare que sea tenido y obligado de dar toda la cantidad de maravedís que fuesen menester para cumplir y pagar el dicho mi testamento y codicilo... y todo lo que restare en su poder, cumplido he dicho mi tes- 
tamento y codicilos, quiero que todo lo entregue al dicho Pedro Fernández de Tuy, mi padre... Y asimismo, mando que todas las otras deudas que a mí se me deben fuera de las dichas Indias en cualesquier partes y lugares, que todas vengan a poder del dicho Juan de Oñate y que él las haya y reciba y cobre y tenga en su poder para acudir con todo ello al dicho mi padre... Y para todo ello yo le doy poder cumplido... Y mando que por cuanto Juan Romes, curtidor, vecino de esta ciudad de Sevilla, ha gastado en mi enfermedad alguna contía de maravedís por mi [683v.] mando que todo lo que él declare en su conciencia que hubiere gastado, le sea descontado, recibido en cuenta de una deuda que me debe de trescientos ducados, que en mi testamento tengo declarados. Y asimismo, mando que todos los maravedís que Alonso de Noya, mi primo y mi albacea, declarare en su conciencia y juramento que sobre ello haga que yo le debo, según él lo diere por su cuenta con el dicho juramento, que todo le sea pagado de mis bienes; y en todo lo al en los dichos mi testamento y codicilos contenido lo ratifico y apruebo... Fecha la carta de codicilo en Sevilla estando en las casas de la morada del dicho Alonso de Noya, que son en esta dicha ciudad de Sevilla, en la collación de San Marcos, lunes, 3 días del mes de julio, año del nacimiento de nuestro Salvador Jesucristo de 1514 años. Y porque no pudo firmar por su enfermedad...

[683r.] CODICILO: En el nombre del muy alto... yo Sebastián de Ocampo... ratificando y aprobando... la carta de testamento... y asimismo dos codicilos que hice... (682 vto.) y queriendo... añadir y acrecentar algunas cosas cumplideras a descargo de mi ánima y conciencia; por ende, otorgo y conozco que hago y ordeno este mi codicilo en el cual mando a Alonso de Noya, mi primo y mi albacea, una mi mula pardilla que yo tengo enfrenada y ensillada; la cual le mando graciosamente por el mucho amor que le tengo y muchas honras y buenas obras que de él he recibido. Y mando a Inés Romes, mujer del dicho Alonso de Noya, cinco mil maravedís por el mucho amor que le tengo y muchas honras y buenas obras que me ha hecho en mi enfermedad. Y mando a Beatriz de Gallegos, mujer pobre, por amor a Dios y por servicios que me ha hecho, una saya nueva de paño de [...] Y mando a Juana García, moza que me sirve, un mantillo de florete nuevo por amor de Dios y por servicios que me ha hecho. Y por esta carta de mi codicilo hago gracia y suelta a Juan de Llamas, vecino de esta ciudad de Sevilla, de un castellano de oro, de los nueve ducados de oro que confieso que él me debe, de un caballo que le vendí, la cual gracia le hago porque es hombre necesitado... Y mando que toda la ropa de mi vestir la den a Francisco Guillén, clérigo, mi confesor, beneficiado de la iglesia de San Marcos, para que él la distribuya en los pobres que él quisiere que lo hayan menester porque rueguen a Dios por mi ánima. Y mando que cuando mi señor fuere servido de me llamar de esta presente vida que mi cuerpo se lleve a enterrar por la ciudad y no por el campo porque los que me vieren rueguen a Dios por mi ánima... Y en todo lo al en el dicho mi testamento y codicilos contenido ratifico y apruebo... 


\section{CARMEN MENA GARCÍA}

[682r.] Fecha la carta de codicilo en Sevilla, estando en las casas de la morada del dicho Alonso de Noya, que son en esta dicha ciudad, en la collación de San Marcos, jueves, 6 días del mes de julio, año del nacimiento de nuestro Salvador Jesucristo de 1514 años. Y porque no pudo firmar por su enfermedad...

[681v.] Sepan cuantos esta carta vieren cómo yo Sebastián de Ocampo, estante que soy en esta ciudad de Sevilla, en nombre y en voz de Vasco Núñez de Balboa, capitán que fue de su Alteza en Tierra Firme y por virtud del poder que de él digo que tengo, el cual me otorgó ante cierto escribano público de Tierra Firme, el cual dicho poder ahora está en poder del señor Lope Conchillos, secretario de su Alteza, el cual dicho poder es para ciertas cosas en él contenidas que yo traje por comisión suya para negociar con su Alteza, otorgo y conozco que sustituyo... a Alonso de Noya, mercader, vecino de esta ciudad de Sevilla en la collación de San Marcos y a (blanco) Cobos, oficial del dicho señor secretario Lope Conchillos, ambos a dos juntamente y a cada uno de ellos por sí in solidum... Fecha la carta en Sevilla, estando en las casas de la morada del dicho Alonso de Noya, que son en esta son en esta dicha ciudad, en la collación de San Marcos, lunes, 26 de junio de 1514 años. Y porque no pudo firmar por su enfermedad...

[681r.] Sepan cuantos esta carta vieren como yo Sebastián de Ocampo, estante que soy en esta ciudad de Sevilla, otorgo y conozco a vos Alonso de Noya, mi primo, vecino que sois de esta ciudad de Sevilla en la collación de San Marcos, que estáis ausente... que por cuanto yo tenía cierto poder de Vasco Núñez de Balboa, capitán que fue de su Alteza en Tierra Firme, que me dio y otorgó para solicitar en su nombre con su Alteza ciertas cosas; el cual dicho poder yo dejé en poder de Lope Conchillos, secretario de su Alteza, y yo en nombre del dicho Vasco Núñez os sustituí en el dicho poder a vos y a (blanco) Cobos, oficial del dicho señor secretario... [680v.] ... por ende, yo otorgo y prometo y me obligo de os dar para vuestras costas y expensas que en la dicha negociación habéis de poner, según que en un memorial e instrucción que os daré para lo susodicho se contendrá, una mula pardilla que yo tengo ensillada y enfrenada y más cuarenta ducados de oro para que la dicha mula y los cuarenta ducados de oro lo hayáis todo vos el dicho Alonso de Noya para vos como cosa propia vuestra por razón del dicho vuestro trabajo y costas; los cuales dichos cuarenta ducados de oro yo quiero y he por bien y mando a Juan de Oñate, platero, vecino de esta ciudad de Sevilla, os de y pague luego como vos el dicho Alonso de Noya viniéreis a esta ciudad de Sevilla y que os los dé para la dicha negociación, y que los dichos ducados de oro sean los que a él les sobren en su poder, sacados los seiscientos ducados que yo tengo dejados y mandados para una capellanía que tengo dotada y mandada en mi testamento que hice y otorgué ante Manuel de Segura, escribano público de Sevilla, y así dándoos los dichos cuarenta ducados de oro, como dicho es, mando que le sean recibidos en cuenta al dicho Juan de Oñate de los pesos de oro que en su poder tiene míos. Y mando y quiero que no se entienda perjudicar, ni estorbar en cosa alguna la data 
«AQUÍ YACE SEBASTIÁN DE OCAMPO, QUE DIOS PERDONA»

de los dichos cuarenta ducados de oro que el dicho Juan de Oñate os ha de dar, como dicho es, o decir que vos el dicho Alonso de Noya me debéis cincuenta ducados de oro, que en mi testamento tengo declarados, porque aquellos los ha de cobrar el dicho Juan de Oñate de vos el dicho Alonso de Noya al tiempo que los habéis de pagar para cumplir lo que yo tengo declarado en mi testamento; y que así recibidos los dichos cuarenta ducados de oro y la dicha mula, seáis obligado vos el dicho Alonso de Noya a ir a hacer luego la dicha negociación delante de su Alteza y de poner en ella toda la diligencia [680v.] que convenga. Y si no quisiéreis vos el dicho Alonso de Noya aceptar de ir a hacer lo susodicho, quiero que no os sean dados, ni pagados los dichos cuarenta ducados de oro ni la dicha mula. Y otorgo y me obligo de tener y cumplir todo lo aquí contenido... so pena de cincuenta mil maravedís... da poder a jueces... Fecha la carta en Sevilla, estando en las casas de la morada del dicho Alonso de Noya, lunes, veinte [679v.] y seis días del mes de junio, año del nacimiento de nuestro Salvador Jesucristo de 1514 años. Y porque no pudo firmar con su flaqueza y enfermedad...

Recibido el 28 de junio de 2011

Aceptado el 06 de junio de 2012

\section{Bibliografía}

Acosta, Antonio: «Intereses privados en la administración de la Monarquía. La Casa de la Contratación (1503-1535)», en Acosta, A., González, A. y Vila, E. (coords.): La Casa de la Contratación y la navegación entre España e Indias, Sevilla, Universidad de Sevilla-CSIC-Fundación El Monte, 2003, 341-374.

Altolaguirre Duvale, Ángel de: Vasco Núñez de Balboa, Madrid, Imprenta del Patronato de Huérfanos e Intervención Militares, 1914.

Bernal, Antonio Miguel: La financiación de la Carrera de las Indias, 1492-1824. Dinero y crédito en el comercio colonial español con América, SevillaMadrid, Fundación el Monte 1992.

Céspedes del Castillo, Guillermo: Las Casas de Moneda en los Reinos de Indias, volumen I, Las Cecas Indianas en 1536-1825. Madrid, Museo Casa de la Moneda, 1996.

Enciso Contreras, José: Testamentos y bienes de difuntos de Zacatecas (15501604), Tribunal Superior de Justicia, Zacatecas, 2000.

Fernández de Oviedo, Gonzalo: Historia General y Natural de las Indias, Edición de Juan Pérez de Tudela, 5, Madrid, B.A.E., 1959.

Giménez Fernández, Manuel: Bartolomé de las Casas, volumen I: Delegado de Cisneros para la reformación de las Indias (1516-1517), volumen II: 
Capellán de S.M. Carlos I, poblador de Cumaná (1517-1523), Sevilla, E.E.H.A., 1960.

Heredia Moreno, $\mathrm{M}^{\mathrm{a}}$ Carmen: «Artistas y artesanos vascos del siglo XVI en la Carrera de Indias», en Escobedo Mansilla, Ronald, Zaballa Beascoechea, Ana de y Álvarez Gila, Oscar (coords.): Euskal Herria y el Nuevo Mundo: la contribución de los vascos a la formación de las Américas, Vitoria Gasteiz, Universidad del País Vasco, 1996, 555-566.

Las Casas, fray Bartolomé de: Historia de las Indias, Madrid, B.A.E., 1957, Estudio y notas de J. Pérez de Tudela.

Le Goff, Jacques: La civilization de l Occident medieval, Paris, Flammarion, 1982.

Manzano y Manzano, Juan y Fernández Heredia, A.M.: Los Pinzones y el descubrimiento de América, 3, Madrid, Editorial Cultura Hispánica, 1988.

Medina, José Toribio: El descubrimiento del Océano Pacífico: Vasco Núñez de Balboa, Hernando de Magallanes y sus compañeros, 2, Santiago de Chile, Imprenta Elzeviriana, 1913.

Mena García, Carmen: Un linaje de conversos en tierras americanas. Los testamentos de Pedrarias Dávila, gobernador de Castilla del Oro y Nicaragua, León, Servicio de Publicaciones de la Universidad de León, 2004.

Mena García, Carmen: El oro del Darién. Entradas y cabalgadas en la conquista de Tierra Firme (1509-1525), Sevilla, Centro de Estudios Andaluces, CSIC, 2011.

Mena García, Carmen: «Preparativos del viaje de Diego de Nicuesa para poblar la Tierra Firme. Sevilla y los mercaderes del comercio atlántico (1509)», Revista de Indias (en prensa).

Mira Caballos, Esteban: «En torno a la expedición de Sebastián de Ocampo a la Isla de Cuba (1506)», Revista de Indias, 56-206, Sevilla, 1996, 199-205.

Schäfer, Ernesto: El Consejo Real y Supremo de las Indias, 2, Sevilla, Universidad de Sevilla, Publicaciones del Centro de Estudios de Historia de América, 1935.

Serrano Sanz, Ma Jesús: «Plateros de la catedral de Sevilla en la primera mitad del siglo XVI y sus relaciones con América», en Estudios de platería. San Eloy, 2010. Murcia, 2010, 717-738. 